\title{
MULTIDISCIPLINARITY IN AUDIOVISUAL TRANSLATION
}

\author{
Elena di Giovanni \\ Università degli studi di Macerata (Italy) \\ elena.digiovanni@unimc.it \\ Pilar Orero \\ Universitat Autònoma de Barcelona (Spain) \\ pilar.orero@uab.cat \\ Rosa Agost \\ Universitat Jaume I (Spain) \\ agost@trad.uji.es
}

The practice of boundary-crossing in research, although regarded with suspicion up until a few decades ago, is now widely accepted and increasingly more common in many domains. In an era dominated by globalized, instant communication, nothing can be seen as monolithic anymore, and this new situation demands a multifarious outlook on the part of the researcher. In the wake of this new trend, as Willy Østreng puts it (2010: 95), scientific disciplines are nowadays subject to vertical as well as horizontal restructuring:

The traditional monodisciplinary organization of research is gradually fading away, and a new structure, based on two distinct pillars is emerging. The first pillar is the fragmentation and hybridization resulting in units of topical specialization and sub-disciplines, and the second is extended monodisciplinarity, where research is moved by "imperialistic expansion" into the territory of other disciplines, either by breaking or bridging across boundaries.

The two pillars around which the breaking up of monodisciplinarity is reorganized, in Østreng's words, can be said to apply to, and portray, the evolution of Translation Studies (TS) and Audiovisual Translation Studies (AVTS). 
The hybridization and fragmentation of the "parent discipline" (TS), as a consequence of its very expansion and contamination, has in turn resulted in the emergence of sub-disciplines. AVTS, as a derivative research field, has soon achieved the "status" of a full-fledged discipline, attracting numerous researchers and leading to the organization of countless conferences, seminars, university courses and publications.

Subsequently, the coming of age of AVTS in the last decade or so has coincided with a more decisive move into the territory of other disciplines, without any imperialistic ambition but rather in search of more solid instruments for the analysis of ever-changing scenarios, techniques and activities. Looking at the plethora of publications and conferences devoted to AVT and its study over the past two or three years, one cannot but notice a major thrust towards multidisciplinarity: even though it was probably never mono-, by asserting its own identity as a truly multi-disciplinary research field, AVTS has signed its own evolution.

But is multidisciplinarity really the way forward in research, especially AVT research? In the introduction to Conceptual Foundations for Multidisciplinary Thinking, Stephen J. Kline (1995: 3-4) sums up three basic reasons why multidisciplinarity is a necessity today. First of all, there is an increased awareness of the impossibility of perceiving human knowledge as a whole, as a single meaningful pattern: hyper-specialization in professional practices and in research makes it very difficult to comprehend increasingly complex, multisemiotic entities and phenomena, if it is not from a multidisciplinary perspective. Hyper-specialized domains themselves are very often characterized by sub-units which are not equally known to their experts. In audiovisual translation studies, for instance, specialists of the more traditional interlingual practices like subtitling often have very little knowledge of what is known as media accessibility (audio description, respeaking, etc.).

Secondly, in Kline's terms, every such complex entity or phenomenon displays what he calls "emergent properties" (ibid.), which stem out of the interaction of different parts or sub-systems. In audiovisual translation, new or "merging modalities"1 frequently arise out of established practices. See, for instance, the surge of audiosubtitling as a mixture of voice over and subtitling and as a complement to audio description.

Finally, in Kline's words, there is a pragmatic reason why multidisciplinarity is indeed a winning approach: the joining of specialized competences and

1. "Merging modalities" was the title of one of the main panels at the 2011 Advanced Research Seminar on Audio Description held in Barcelona in March, 2011. 
the acknowledgement of emergent properties is (and has to be) supported by a true will to work interdependently, to make such interdependence work. As Kline puts it, "It is not enough to assemble a multidisciplinary group: the individual people must themselves be multidisciplinary or willing to become so" (ibid.)

Collaboration among AVT scholars has always been the norm, within what has developed as a friendly research environment from its very onset. Due, in all likelihood, to the vibrant nature of audiovisual translation itself, the research community which has gathered around it has enhanced the development of a solid but also extremely dynamic domain. In the wake of the discipline's internal drift, AVT scholars have always looked across and beyond: multidisciplinarity has been sought at various degrees, and this has led to innovative research paths, viewpoints and practices.

But is multidisciplinarity the best possible way forward for AVTS? And most importantly, does it really have to be multi- rather than inter-, or perhaps transdisciplinary (Brown et al. 2010)? Although often used interchangeably, multidisciplinarity and interdisciplinarity have been distinguished by a number of scholars, in terms of the degree of integration among disciplines and methods. In other words, it seems that multidisciplinarity implies the parallel recourse to different approaches, whereas interdisciplinarity stands for their true blending. This attitude has often led to a negative connotation being attached to multi- as opposed to inter-; as Lattuca reports (2011: 11), for instance,

Rossini and Porter (1984) likened interdisciplinary work to a seamless woven garment that stands in contrast to the patchwork quilt of multidisciplinary work - in true interdisciplinary projects, a concatenation of disciplinary perspectives is replaced by integration of those perspectives.

On the other hand, supporters of transdisciplinarity generally unite multi- and inter-approaches under the umbrella of the coming-together-of-disciplines, in contrast to a seemingly more fruitful "overarching synthesis that transcends disciplinary worldviews [and should be] the ultimate goal of disciplinary cooperation" (ibid.). On yet another different note, Lawrence and Després (2004) compare interdisciplinary approaches to a mixing of disciplines, while transdisciplinarity would have more to do with a fusion of those disciplines (thus attaching to trans- and inter- the distinction more frequently made between multiand inter-). Many scholars have then moved forward in the elaboration of concepts and terms related to the coming close or coming together of research approaches: interdisciplinarity has been further distinguished as auxiliary, linear or methodological, or as instrumental and conceptual (cf. Lattuca 2001: 11). 
All of these distinctions have been briefly reported to show that even the definition of the coming together of research approaches is, in itself, dynamic and open to question, just like the disciplines themselves.

With reference to AVTS, in virtue of its being a young and undoubtedly multifarious domain, the editors of this volume have deliberately opted for a multidisciplinary perspective, with a view to stressing precisely that multifarious nature, where different elements, viewpoints, techniques and practices can be observed together. Moreover, the choice of multi- over inter-advocates for the integration of approaches but not their systematic or perpetual fusion: integration rather than fusion can lead to discoveries, redefinition and recombination in a never-ending, always-growing process.

This volume bears witness to the multidisciplinary essence of today's audiovisual translation studies and to the prolific nature of this discipline, which are reflected in the ever-growing number of monographs and collections that have appeared in the past few years (see below the selected bibliography of books since the year 2000). Monographs have so far largely focused on one AVT technique, thus filling a bibliographical and theoretical void, and the collections of essays have been, and still are, a privileged ground for highlighting the growing multidisciplinary attitude of AVTS scholars and professionals. The volume here presented is perhaps the first to spell out the multidisciplinarity of this domain, in an attempt to highlight and further enhance this attitude.

Looking back at the first article on bibliometrics in AVT (Franco \& Orero 2005: 83), the prediction seems to have materialized: "While it is still early to draw any solid conclusions about the beginning of the 21st century, it seems clear that there is a rising tendency and dynamism in the field of AVT which should consolidate it in a non-distant future". Franco \& Orero analysed publications by decades, but finished in 2000. Writing at the end of 2011 offers us the opportunity to update the trends of the last decade, and also forecast the future.

Regarding research topics, this first decade of the new millennium continues mainly with descriptive studies. Articles focusing on a particular film director or film seem to still capture academic interest. Not much progress has been made in building a general theoretical background for this discipline, and perhaps given the multidisciplinary and multisectorial nature of the field, with the many (and still growing) approaches to research methodology, it is a chimera to think that a theory encompassing all disciplines will ever be achieved. 
Regarding translation modalities, previous research had been bipolar, in the sense that dubbing or subtitling were the two translation modalities under the microscope -subtitling enjoying the lion's share. This hegemony continued in the new decade with monographs such as Lorenzo \& Pereira 2001, Díaz Cintas 2001 \& 2003, Bogucki 2004, Sanderson 2005, Díaz Cintas \& Remael 2007, Downey 2008, Bannon 2009, McLoughlin, Biscio \& Mhainnín 2011, and Pedersen 2011. Dubbing has also been gathering attention (Chaves 2000, Lorenzo \& Pereira 2000, O'Connell 2003, Paolinelli \& Di Fortunato 2005, Perego 2005, Pavesi 2006) or both these mainstream techniques (Petillo 2008, Ranzato 2011). Interestingly the field has recently opened up to other practices, such as voice-over (Franco, Matamala \& Orero 2010), respeaking (Romero Fresco 2011), and audio description (Perego 2012). A look at the immediate future tells us that more monographs are to come, the aim being to expand the knowledge of mainstream AVT techniques and most of all to explore ever-growing activities and areas of interest. By the end of 2012, several volumes on audio description and video game translation will have been published (O'Hagan \& Mangiron forthcoming), thus also bearing witness to the latest trends and the avenues that are being developed within AVT research. The controversy of where AVT ends as a field is a hobbyhorse for those who still believe in self-contained areas of knowledge. We could have also listed volumes on the translation of theatre, opera, music, comics, songs, web localisation, etc. and the present volume is a witness of the permeability of the studies, which will no longer be widespread when technology and imagination in new communication formats ceases to be the context of today society.

A quick look at some collections of essays which have been published to date tells us that the juxtaposition of viewpoints, practices and research attitudes has always been common within AVTS. In 2001, Henrik Gottlieb and Yves Gambier edited a volume for John Benjamins whose very title was revealing of the multi- essence of AVT: (Multi)Media Translation: Concepts, Practices, and Research spelled out the complex and extremely dynamic nature of the practice and study of AVT and paved the way for a host of other volumes. In 1999, one of the first international conferences on AVT was held at the Universitat Jaume I (Spain). As a result, Agost \& Chaume (2001) edited a volume devoted to a wide range of subjects from a theoretical and professional standpoint: different modalities, languages, and methodologies. In their introduction, the editors point out the importance of the new avenues and trends on AVT research, particularly as this was, at that time, new academic aspects of Audiovisual Translation: 
Es innecesario insistir en el papel que ha adquirido la comunicación audiovisual en estos últimos años. Las plataformas digitales, las televisiones vía satélite, la televisión por cable, el auge del cine, del vídeo y de la televisión, la irrupción de los productos multimedia en los hogares, el futuro, ya inmediato, de las nuevas tecnologías aplicadas a los medios audiovisuales, como el DVD, la elección de la lengua en el visionado de un filme, la subtitulación para sordos, la narración para ciegos [sic], entre otras, se disponen a inaugurar un milenio caracterizado por la comunicación audiovisual. (Chaume \& Agost 2001: 9-10)

Pilar Orero's Topics in Audiovisual Translation (2004), also published by John Benjamins, highlighted the main issues at stake in the study of AVT at the beginning of the new millennium, as well as introducing new topics and research attitudes. A few years later, the titles of collective volumes started to bring to the fore newly emerged areas of investigation (Catalina Jiménez's 2007 volume Traducción y accesibilidad. Subtitulación para Sordos y audiodescripción para ciegos: nuevas modalidades de Traducción Audiovisual and the first volume of Media for All published in the same year by Díaz Cintas, Orero $\&$ Remael on Subtitling for the Deaf, Audio Description and Sign Language), in addition to the very need to explore AVT from broader perspectives (Neves $\&$ Remael's 2007 volume A Tool for Social Integration? Audiovisual Translation from Different Angles). A year later, a collection of essays proposed the first systematic reflection on the training of audiovisual translators for such diverse and dynamic practices (Díaz Cintas's 2008 volume The Didactics of Audiovisual Translation). On the whole, that same year seems to have marked the acknowledgement of the unexpected expansion of AVTS, with scholars looking for order (cf. Chiaro, Heiss \& Bucaria) and once again spelling out the need for a complex, pluridisciplinary approach to the study of certain activities (Lavour \& Serban's 2008 volume Le sous-titrage des films - approches pluridisciplinaires). Dozens of other collective volumes have been published within the past three years, highlighting to varying degrees the growing interest in AVT practices and research, their ever-changing faces and, more or less overtly, the need for truly multidisciplinary reflections.

Most articles within AVTS are still signed by one or two authors who are very often from the same university. This trend may be due to the fact that in the Humanities more than two authors still appears to be a crowd and publication impact is diminished when used for benchmarking. Be it as it may, one important change in the field will be the acceptance from evaluating bodies of a larger number of authors for one article, thus breaking the alphabetical signing order (Rovira-Esteva \& Orero 2011, and forthcoming). 
Looking at the present and the immediate future, AVTS continues with the trend of publication in either collective works (see the bibliography below) or special issues of journals. Not many articles are published outside of these two formats, and paper still holds the weight of quality, though it is hoped that online publications soon come of age and are rated by their content, and not merely their format. The shift from paper to online is not only a long-term demand, but a prerequisite when studying multimedia. Long paragraph describing examples studied in an article could easily be replaced with excerpts from films or other multimedia texts, although this obviously raises questions regarding copyright. Away from the dilemma of the most natural format for audiovisual publications, we find the current trend of students relying almost exclusively on bibliography which can be found instantly online. Perhaps the battle against paper will come to an end soon, when publication impact indexes reveal the unrelenting trend towards quoting and referring to online resources rather than traditional publications. However, considering the extremely vibrant nature of AVTS as well as the practices and texts it is concerned with, it is difficult to make any sound forecasts.

It is, however, possible to envisage some of the major trends which are currently animating AVTS by taking a closer look at the papers which appear in this volume. The following essays reveal a multidisciplinary approach. Drawing from pragmatics and cognitive studies, relying on the principles of acoustic or eye-tracking research, these essays are representative of a wide range of new trends on audiovisual translation research.

The multilingual cinema analysis is considered with regard to the cultural and linguistic variety, richness and nuances of the filmic texts and the target audience receptiveness. Aspects that are not well covered until now, for example the importance of luminance and their relevance to the translation process and reception, are included in this volume. From the standpoint of modalities, this monograph deals with subtitling, dubbing, video game localization and accessibility (subtitling for deaf and heard-of-hearing, audio description, interpreting, audio guides, etc.). This situation reflects the desire to offer a panoramic vision about all the ways the target audience receives the audiovisual products today.

According to the methodologies used, descriptive analysis of dubbing and subtitling, or audio description analysis carried out from a narratological point of view, coexist with more empirical analysis. Experiments with eyetracking technology or reception studies based on sociological inquiries are the crux of the presented works. 
Regarding the codes used, we have articles focused on light, sound in general, and music in particular. With regards to image, there are works that deal with the visual features that should be transferred to the audiodescription.

To finish, the editors of this volume would insist on the continuation of the work dedicated to push barriers that still exist in the field of Audio Visual Translation Studies. We need researchers working in different fields; applied research taking account of two or more disciplines; and, finally, we need an identification of problems that are not centred on one specific subject. We must continue our efforts to connect individual and collective interests.

Ilya Prigogine, Nobel Prizewinner of Chemistry, says that there is nothing so complex that cannot be organized. If that statement is true for Physics, then we believe it can be applied to translation. It is our hope that we can continue to better organize AVT in the new context. We suggest there are three domains we should consider: the democratisation of the knowledge on the internet, the transparent ethics with a wider circulation of the new methodologies, and finally, the construction of relationships within the society. The future of the audiovisual translation research should be for all, or it will not be.

\section{References and Selected Bibliography}

Agost, Rosa \& Frederic Chaume (eds.) (2001) La traducción en los medios audiovisuales. Castelló: Publicacions de la Universitat Jaume I.

Agost, Rosa (ed.) (2011) Screens We Live By: An Updated Insight into Audiovisual Translation Research. Special issue of International Journal of Translation 23:2. Anderman, Gunilla \& Jorge Díaz Cintas (eds.) (2009) Audiovisual Translation. Language Transfer on Screen. London: Palgrave Macmillan.

BAllester, Ana. (2001) Traducción y nacionalismo. La recepción del cine americano en España a través del doblaje (1928-1948). Granada: Comares.

Bannon, David. (2009) The Elements of Subtitles: A Practical Guide to the Art of Dialogue, Character, Context, Tone and Style in Subtitling. Korean Language Division. ATA.

BOGUCKI, Lucas. (2004) A relevance framework for constraints on cinema subtitling. Lodz: Wydawnictwo Uniwersytetu Lodzkiego.

BoGUCKI, Lukasz \& K. Kredens (eds.) (2010) Perspectives on Audiovisual Translation. Frankfurt am Main, Berlin, Bern, Bruxelles, New York, Oxford, Wien: Peter Lang.

Bollettieri Bosinelli, Rosa Maria; Christina Heiss; M. Soffritti \& Silvia Bernardini (eds.) (2000) La traduzione multimediale. Quale traduzione per quale testo? Bologna: CLUEB 
BROWN, Valerie A.; John Alfred Harris \& Jacqueline Y. Russell. (2010) Tackling wicked problems through the transdisciplinary imaginati. London/New York: Routledge.

BRUTI, Silvia; Elena di Giovanni \& Pilar Orero (forthcoming) Audiovisual Translation Across Europe: An Ever Changing Landscape. Oxford: Peter Lang.

Chaume, Frederic \& Rosa Agost. (2001) "Horizontes cercanos: la consolidación académica de la traducción audiovisual". In: Agost, Rosa \& Frederic Chaume (eds.) 2001. La traducción en los medios audiovisuales. Castelló: Publicacions de la Universitat Jaume I. pp. 9-15.

CHAume, Frederic. (2003) Doblatge i subtitulació per a la TV. Vic: EUMO.

CHAVES, María José. (2000) La traducción cinematográfica: El doblaje. Huelva: Universidad de Huelva.

Chiaro, Delia; Christine Heiss \& Chiara Bucaria (eds.) (2008) Between Text and Image. Updating research in screen translation. Amsterdam: John Benjamins.

Di Giovanni, Elena (ed.) (2008) Translation, cultures and the media. Special issue of European Journal of English Studies 12:2.

Di GiovanNi, Elena (ed.) (2011) Between text and receiver: translation and accessibility. Frankfurt am Main: Peter Lang.

DíAz CinTAS, Jorge \& Aline Remael. (2007) Audiovisual Translation: Subtitling. Manchester: St. Jerome.

DíAz Cintas, Jorge (ed.) (2008) The Didactics of Audiovisual Translation. Amsterdam: Benjamins.

DíAz CinTAS, Jorge. (2001) La traducción audiovisual. El subtitulado. Salamanca: Almar.

Díaz Cintas, Jorge. (2003) Teoría y práctica de la subtitulación. Barcelona: Ariel.

DíAz CinTAS, Jorge; Anna Matamala Ripoll \& Josélia Neves (eds.) (2010) New Insights into Audiovisual Translation and Media Accessibility. Media for All 2. Amsterdam: Rodopi.

DíAZ CinTAS, Jorge; Pilar Orero \& Aline Remael (eds.) (2007) Media for All: Subtitling for the Deaf, Audio Description and Sign Language. Amsterdam: Rodopi.

Downey, Gregory J. (2008) Closed Captioning: Subtitling, Stenography, and the Digital Convergence of Text with Television. Baltimore: The Johns Hopkins University Press.

DuRO, Miguel (ed.) (2001) La traducción para el doblaje y la subtitulación. Madrid: Cátedra.

FONG, Gilbert G. F. \& Kenneth K. L. Au (eds.) (2009) Dubbing and Subtitling in a World Context. Hong Kong: The Chinese University Press.

FrANCO, Eliana; Anna Matamala \& Pilar Orero (2010) Voice-over Translation: An overview. Frankfurt am Main, Berlin, Bern, Bruxelles, New York, Oxford, Wien: Peter Lang. 
FrANCO, Javier \& Pilar Orero. (2004) "Research on Audiovisual Translation: Some Objective Conclusions, or the Birth of an Academic Field”. In: Sanderson, John D. (ed.) Research on Translation for Subtitling in Spain and Italy. Alicante: Universidad de Alicante. pp. 79-92.

GAMBIER, Yves \& Henrik Gottlieb (eds.) (2001) (Multi)media Translation. Concepts, Practices, and Research. Amsterdam: John Benjamins Publishing Company.

JimÉnez Hurtado, Catalina (ed.) (2007) Traducción y accesibilidad. Subtitulación para sordos y audiodescripción para ciegos: nuevas modalidades de Traducción Audiovisual. Frankfurt am Main, Berlin, Bern, Bruxelles, New York, Oxford, Wien: Peter Lang.

KLINE, Stephen Jay. (1995) Conceptual foundations for multidisciplinary thinking. Stanford: Stanford University Press.

Lavour, Jean Marc \& Adriana Serban (eds.) (2008) Le sous-titrage des films approches pluridisciplinaires. Louvain-la-Neuve: De Boeck.

LATTUCA, Lisa R. (2001) Creating interdisciplinarity: interdisciplinary research and teaching among college and university faculty. Nashville: Vanderbilt University Press.

LAWRENCE, Roderick J. \& Carole Després (eds.) (2004) Futures of transdisciplinarity. Special issue of Futures 36:4.

Lorenzo, Lourdes \& Ana María Pereira (eds.) (2000) Traducción Subordinada I El Doblaje. Vigo: Universidad de Vigo.

Lorenzo, Lourdes \& Ana María Pereira (eds.) (2001) Traducción Subordinada II El Subtitulado. Vigo: Universidad de Vigo.

Matamala, Anna \& Pilar Orero (eds.) (2009) Listening to Subtitles. Subtitles for the Deaf and Hard of Hearing. Frankfurt am Main, Berlin, Bern, Bruxelles, New York, Oxford, Wien: Peter Lang.

Mcloughlin, Laura I.; Marie Biscio \& Máire Áine Ní Mhainnín (eds.) (2011) Audiovisual Translation Subtitles and Subtitling. Theory and Practice. Oxford, Bern, Berlin, Bruxelles, Frankfurt am Main, New York, Wien: Peter Lang.

O'Connell, Eithne M. T. (2003) Minority Language Dubbing for Children. Oxford, Bern, Berlin, Bruxelles, Frankfurt am Main, New York, Wien: Peter Lang.

O'HAGAn, Minako \& Carme Mangiron (forthcoming) Game Localization: Translating for the Global Digital Entertainment Industry.

Orero, Pilar (ed.) (2004) Topics in Audiovisual Translation. Amsterdam: Benjamins. ØSTRENG, Willy. (2010) Science without boundaries: Interdisciplinarity in research, society, and politics. Lanham, Maryland: University Press of America.

Paolinelli, Mario \& Eleonora Di Fortunato. (2005) Tradurre per il doppiaggio. Milano: HOEPLI.

PAVESI, Maria. (2006) La Traduzione Filmica. Aspetti del parlato doppiato dall'inglese all'italiano. Roma: Carocci. 
Pedersen, Jan. (2011) Subtitling Norms for Television. An exploration focussing on extralinguistic cultural references. Amsterdam: John Benjamins.

Perego, Elisa. (2005) La traduzione audiovisiva. Roma: Carocci.

Perego, Elisa (ed.) (2012) Emerging topics in translation: audio description. Trieste: ETU

Petillo, Mariacristina. (2008) Doppiaggio e sottotitolazione: problemi linguistici e traduttivi nel mondo della 'screen translation'. Bari: Digilabs.

RANZATO, Irene. (2011) La traduzione audiovisiva. Analisi degli elementi culturospecifici. Roma: Bulzoni.

Remael, Aline \& Josélia Neves (eds.) (2007) A tool for social integration? Audiovisual translation from different angles. Special isuue of Linguistica Antverpiensia New Series, 6.

Remael, Aline; Mary Carroll \& Pilar Orero (eds.) (2012) Media for All 3: The Audiovisual Turn. Amsterdam: Rodopi.

Romero Fresco, Pablo. (2011) Respeaking. Manchester: St. Jerome.

RovirA-Esteva, Sara \& Pilar Orero. (2011) "A Contrastive Analysis of the Main Benchmarking Tools for Research Assessment in Translation and Interpreting: the Spanish Approach". Perspectives 19:3. pp. 233-251.

RovirA-EsteVA, Sara \& Pilar Orero (forthcoming): "Evaluating Quality and Excellence in Translation Studies Research: Publish or Perish, the Spanish Way". Babel.

SANDERSON, John D. (ed.) (2001) ¡Doble o Nada!. Alicante: Universidad de Alicante.

SANDERSON, John D. (ed.) (2002) Traductores para todo. Alicante: Universidad de Alicante.

SANDERSON, John D. (ed.) (2005) Research on Translation for Subtitling in Spain and Italy. Alicante: Universidad de Alicante.

SAnderson, John D. (ed.) (2008) Películas antiguas, subtítulos nuevos. Alicante: Universidad de Alicante.

Serban, Adriana; Jean-Marc Lavour \& Anna Matamala (eds.) (2011) Audiovisual translation in close-up: practical and theoretical approaches. Frankfurt am Main, Berlin, Bern, Bruxelles, New York, Oxford, Wien: Peter Lang.

TAYLOR, Christopher J. (ed.) (2002) Tradurre il Cinema. Trieste: Università degli Studi di Trieste.

TVEIT, Jan Emil. (2004) Translating for Television. Bergen: JK Publishing.

ZabAlBEASCOA, Patrick; Laura Santamaria \& Frederic Chaume (eds.) (2005) La Traducción Audiovisual. Investigación, Enseñañza y Profesión. Granada: Comares. 


\section{BIONOTES / NOTAS BIOGRÁFICAS}

\section{Elena di Giovanni}

Elena Di Giovanni is Lecturer in Translation at the University of Macerata (Italy), where she is also Director of the Language Centre. She holds a degree in specialized translation and a PhD in English and audiovisual translation. She has taught audiovisual translation theory and practice at the MA in screen translation of the University of Bologna and the University of Parma (Italy). For three years she has also been lecturing at the MA in audiovisual translation of Roehampton University, London, UK. In September, 2011, she organized the first Italian training course in audio description at the University of Macerata.

Her research focuses on audiovisual translation, in particular subtitling and audio description. She has also published extensively on translating for children and translation as intercultural communication. Her recent publications include: Between Text and Receiver: Translation and Accessibility (Peter Lang), Oltre l'Occidente. Traduzione e Alterità Culturale (Bompiani), Translation, Cultures and the Media (Routledge). She has been in the audiovisual translation industry for more than 15 years.

Elena Di Giovanni es profesora de traducción en la Universidad de Macerata (Italia), donde también ostenta el cargo de directora del Centro de Lenguas. Es licenciada en traducción especializada y doctora en anglística y traducción audiovisual. Ha enseñado teoría y práctica de traducción audiovisual en el máster en traducción audiovisual de la Universidad de Bolonia y de la Universidad de Parma (Italia). Desde hace tres años también imparte clases de traducción audiovisual en la Universidad de Roehampton (Londres). En septiembre de 2011, organizó el primer curso italiano de audiodescripción, que se celebró en la Universidad de Macerata.

$\mathrm{Su}$ principal campo de investigación es la traducción audiovisual, especialmente el subtitulado y la audiodescripción. También ha realizado numerosas publicaciones sobre traducción infantil y traducción como comunicación intercultural. Entre sus últimas publicaciones cabe destacar: Between Text and Receiver: Translation and Accessibility (Peter Lang), Oltre l'Occidente. Traduzione e Alterità Culturale (Bompiani), Translation, Cultures and the Media (Routledge). Lleva más de 15 años implicada en la industria de la traducción audiovisual. 


\section{Pilar Orero}

PhD (UMIST). Works in the CAIAC Research Centre (Universitat Autònoma de Barcelona, Spain). She started the two MAs in Audiovisual Translation at $\mathrm{UAB}$, and now is the director of the Online European MA in Audiovisual Translation (http://mem.uab.es/metav/). Recent publications: Topics in Audiovisual Translation (2004), John Benjamins. Co-editor with Jorge Díaz-Cintas and Aline Remael of Media for All: Subtitling for the Deaf, Audio Description and Sign Language (2007), Rodopi. Co-editor with Anna Matamala of Listening to Subtitles: SDHoH (2010) in Peter Lang. Co-writer with Anna Matamala and Eliana Franco of Voice-over: An Overview (2010) in Peter Lang. Guest editor of TRANS 11 and co-guest editor with J.L. Kruger of Perspectives on Audio Description (2010). Leader of numerous research projects funded by the Spanish and Catalan Gov. Partner of the EC project DTV4ALL (http://www. psp-dtv4all.org/). Leads TransMedia Catalonia (http://grupsderecerca.uab.cat/ transmediacatalonia)

Doctora por la UMIST. Treballa al Centre de Recerca CAIAC (Universitat Autònoma de Barcelona, Espanya). Propulsora de dos màsters en Traducció Audiovisual a la UAB, i actualment directora del Màster Europeu de Traducció Audiovisual (http://mem.uab.es/metav/). Publicacions recents: Topics in Audiovisual Translation (2004), John Benjamins. Coeditora amb Jorge DíazCintas i Aline Remael de Media for All: Subtitling for the Deaf, Audio Description and Sign Language (2007), Rodopi. Coeditora amb Anna Matamala de Listening to Subtitles: SDHoH (2010) a Peter Lang. Coautora amb Anna Matamala i Eliana Franco de Voice-over: An Overview (2010) a Peter Lang. Editora convidada de TRANS 11 i coeditora convidada amb J.L. Kruger de Perspectives on Audio Description (2010). Investigadora principal de nombrosos projectes de recerca finançats pel Govern espanyol i català. Partner del projecte europeu DTV4ALL (http://www.psp-dtv4all.org/). Directora del grup de recerca TransMedia Catalonia (http://grupsderecerca.uab.cat/transmediacatalonia).

\section{Rosa Agost}

Rosa Agost holds an MA in Translation and Interpreting (1994) and a PhD in Translation Studies, with a dissertation on audiovisual translation, focusing on dubbing (1996). She is a Senior Lecturer at the Department of Translation and Communication at the Universitat Jaume I (Spain), and she collaborates with several Masters in Audiovisual Translation and Translation Studies. She also works as a freelance translator (audiovisual texts for broadcasting, and popular science books). Her main research lines are: Audiovisual Translation 
(Dubbing and Accessibility); Translation Theory and Methodology; Mother Tongues and Translation (Spanish-Catalan). She is the author of Traducción y doblaje: palabras, voces e imágenes (1999), Teoria i pràctica de la traducció. Espanyol-català (2001, with E. Monzó); she is the editor of La traducción en los medios audiovisuales (2001, with F. Chaume) and the guest editor of Screens We Live By: An Updated Insight into Audiovisual Translation Resarch (2011).

Rosa Agost posee un Máster en Traducción e Interpretación (1994) y un doctorado en Estudios de Traducción, con una tesis sobre la traducción audiovisual, concretamente sobre doblaje (1996). Es profesora titular del Departamento de Traducción y Comunicación de la Universitat Jaume I de Castelló y colabora con diversos másteres de Traducción y de Traducción Audiovisual. También trabaja como traductora (textos audiovisuales para la televisión y libros de divulgación científica). Sus líneas de investigación preferentes son la traducción audiovisual, con especial referencia al doblaje y a la accesibilidad; la teoría y metodología de la traducción y la traducción entre lenguas maternas (español-catalán). Es autora de Traducción y doblaje: palabras, voces e imágenes (1999), Teoria i pràctica de la traducció. Espanyol-català (2001, con E. Monzó); editora de La traducción en los medios audiovisuales (2001, con F. Chaume) y editora invitada de Screens We Live By: An Updated Insight into Audiovisual Translation Resarch (2011). 